\title{
Evaluasi Sistem Informasi Skripsi dan Tugas Akhir STMIK Primakara (PRISKA) Menggunakan Metode User Experience Questionnaire
}

\author{
Ni Luh Dithiana Gitajayanti ${ }^{1}$, I Putu Satwika ${ }^{2}$, A.A. Istri Ita Paramitha ${ }^{3}$ \\ ${ }^{1,3}$ Program Studi Sistem Informasi \\ ${ }^{2}$ Program Studi Teknik Informatika \\ STMIK Primakara \\ Denpasar, Indonesia \\ Email: dithianagitaa@gmail.com, satwika@primakara.ac.id, ita@primakara.ac.id
}

\begin{abstract}
Primakara Skripsi dan Tugas Akhir (PRISKA) is an information system that created to manage the final project of students in STMIK Primakara. Within the information system, students can manage the process of final project from the beginning until the end. This research is conduct to evaluate PRISKA as information system from the user experience perspectives. To evaluate the information system, researcher will use User Experience Questionnaire (UEQ) as the usability testing method.

This research respondent are consist of third year students and lecturers in STMIK Primakara. The results of this research shows PRISKA that used by students need to be upgraded and develop because student doesn't give good impressions regarding to the user interface and the user experience. Meanwhile, the results from lecturers show a good impression towards PRISKA user interface and user experience. However, the group of lecturers that use PRISKA wants the information system to improved regarding to the functionalities of the system.
\end{abstract}

Keywords-PRISKA Information System, Usability Evaluation, User Experience Questionnaire

\section{PENDAHULUAN}

Sistem informasi yang diterapkan pada sektor pendidikan, terutama pada perguruan tinggi memiliki manfaat yang mana dapat menjadi faktor kesuksesan dan kemajuan dari perguruan tinggi itu sendiri. Banyak hal yang dapat dilakukan dengan sistem informasi, seperti sistem informasi akademik yang mengatur jadwal belajar mengajar, dosen, mahasiswa dan nilai ataupun sistem informasi perpustakaan yang mengatur pengelolaan data - data buku dalam perpustakaan. Dengan adanya sistem informasi juga akan sangat memudahkan perguruan tinggi menghasilkan informasi yang berhubungan dengan kebutuhan dan kepentingan dalam perguruan tinggi serta memudahkan segala aktivitas perguruan tinggi terkait dengan pengolahan data[1].

Sekolah Tinggi Manajemen Informatika dan Komputer (STMIK) Primakara adalah salah satu perguruan tinggi yang menerapkan sistem informasi, dimana diperuntukkan mahasiswa tingkat akhir yang akan melaksanakan tugas akhir. Sistem Informasi mengenai tugas akhir di STMIK Primakara disebut dengan PRISKA (Primakara Skripsi dan Tugas Akhir). Untuk pengguna sistem informasi PRISKA adalah mahasiswa yang mengambil mata kuliah proposal dan skripsi serta dosen, yang mana pengguna dapat melakukan input informasi terkait tugas akhir seperti melakukan pengajuan judul tugas akhir, melakukan bimbingan, melakukan pemilihan pembimbing, mengatur jadwal terkait seminar dan sidang.

Sistem Informasi PRISKA sudah cukup berfungsi dengan baik, hanya saja masih terdapat beberapa fitur yang membingungkan pengguna, terutama pengguna pemula atau pengguna yang jarang menggunakan sistem ini, contohnya pada mahasiswa yang baru pertama kali menyentuh sistem ini mengalami kebingungan tentang cara penggunaan PRISKA, sehingga mereka pun berinteraksi dengan cara "meraba" sistem. Hal ini dapat menyebabkan efisiensi dan efektivitas dalam melakukan pekerjaan bagi sang pengguna menurun serta pengguna mengalami perasaan tidak puas, sehingga lebih memilih untuk menggunakan cara konvensional yang memakan waktu lebih lama. Hal inilah yang dirasa perlu untuk dilakukannya evaluasi mengenai antarmuka pada PRISKA.

Usability adalah sebuah atribut kualitas yang menilai seberapa mudah antarmuka digunakan[2]. Usability 
e-ISSN: 2685-7006 | p-ISSN: 2252-9063

Kumpulan Artikel Mahasiswa Pendidikan Teknik Informatika

(KARMAPATI)

Volume 10, Nomor 1, Tahun 2021

merupakan hal yang sangat penting pada sebuah website atau aplikasi yang dibuat oleh pengembang. Jika perangkat sulit digunakan, tidak memberikan informasi yang jelas kepada pengguna, sulit dipahami atau tidak menjawab pertanyaan dari para pengguna, maka meninggalkan website atau aplikasi tersebut merupakan garis pertahanan pertama ketika pengguna menghadapi kesulitan.

Terdapat berbagai macam metode evaluasi usability yang bisa digunakan. Pada penelitian ini, peneliti menggunakan metode User Experience Questionnaire (UEQ), dimana UEQ mampu memberikan gambaran dari aspek usability hingga user experience (pengalaman pengguna)[4]. Kelebihan yang dimiliki UEQ adalah dapat mengukur aspek pengalaman pengguna dengan sangat cepat[5] dan penerapan UEQ biasanya dibutuhkan waktu selama $3-5$ menit untuk membaca dan menyelesaikan kuesioner[4].

Berdasarkan paparan di atas, maka dalam penelitian ini, evaluasi terhadap PRISKA dilakukan dengan teknik UEQ untuk mengetahui pengalaman pengguna secara langsung saat berinteraksi dengan sistem informasi PRISKA. Hasil penelitian ini nantinya dapat dijadikan saran atau acuan bagi pengembang sistem informasi PRISKA untuk memperbaiki kualitas dari PRISKA, yaitu pada user interface dan pengalaman pengguna.

\section{TINJAUAN PUSTAKA}

\section{A. PRISKA}

Primakara Skripsi dan Tugas Akhir (PRISKA) merupakan sistem informasi untuk pengelolaan tugas akhir atau skripsi. Pengelolaan yang dimaksud adalah PRISKA dapat melakukan pengajuan topik tugas akhir, pemilihan pembimbing untuk proposal dan skripsi, serta melakukan penjadwalan terkait seminar maupun sidang skripsi. Dalam sistem informasi PRISKA ini terdiri dari pengguna mahasiswa yang mengambil mata kuliah Proposal, dimana terdapat fitur Pengajuan Topik sehingga mahasiswa dapat melakukan pengajuan topik yang akan dijadikan tugas akhir mereka. Kemudian, terdapat fitur Proposal guna mahasiswa untuk melakukan bimbingan selama proses penyusunan tugas akhir. Pada fitur Seminar Proposal, mahasiswa dapat melakukan pendaftaran ujian tugas akhir mereka.

Pada pengguna mahasiswa yang mengambil mata kuliah Skripsi, fitur yang ada tak jauh berbeda dengan mahasiswa yang mengambil mata kuliah Proposal, hanya saja mahasiswa yang mengambil mata kuliah Skripsi tidak perlu melakukan pengajuan topik. User langsung dapat menggunakan fitur Skripsi guna melakukan bimbingan dengan dosen pembimbing. Kemudian, terdapat fitur Sidang Terbuka dan
Sidang Tertutup, dimana mahasiswa dapat melakukan pendaftaran ujian tugas akhir mereka.

Pada pengguna dosen terdapat beberapa fitur, diantaranya dosen dapat melihat jumlah mahasiswa yang dibimbingnya, baik yang mengambil mata kuliah proposal maupun skripsi, yang menjalani seminar maupun sidang terbuka atau tertutup. Kemudian, terdapat fitur daftar bimbingan, yang mana dosen dapat memantau setiap mahasiswa yang melakukan bimbingan. Selanjutnya, dosen dapat melakukan input nilai beserta revisi (jika ada) saat proses seminar atau sidang berlangsung.

\section{B. User Experience Questionnaire (UEQ)}

User Experience Questionnaire (UEQ) merupakan salah satu teknik yang dapat digunakan untuk mengukur pengalaman pengguna, dimana UEQ mampu memberikan gambaran dari aspek usability hingga user experience[4]. Tujuan menggunakan UEQ sebagai tools dalam usability testing adalah untuk memungkinkan penilaian cepat yang dilakukan oleh end user yang mencakup kesan komprehensif yang lebih disukai dari pengguna. Itu harus memungkinkan pengguna untuk mengekspresikan perasaan, kesan dan sikap yang muncul saat memakai produk di bawah investigasi dengan cara yang sangat sederhana dan langsung[7].

Penerapan UEQ biasanya dibutuhkan waktu selama 3 - 5 menit untuk membaca dan menyelesaikan kuesioner[4]. Analisis data juga dapat dilakukan cukup efisien dengan menggunakan Excel-sheet yang telah disediakan. Keunggulan lainnya dari UEQ adalah dapat diakses secara gratis (http://www.ueq-online.org/). Versi asli dari UEQ dirancang dalam bahasa Jerman, namun telah diterjemahkan ke dalam beberapa bahasa, salah satunya Bahasa Indonesia. User Experience Questionnaire (UEQ) mencakup 6 (enam) aspek dengan total 26 butir pernyataan. Masing-masing aspek tersebut adalah:

\section{Daya Tarik (attractiveness)}

Seberapa menarik suatu produk secara persepsi keseluruhan. Item ukuran: annoying/enjoyable, good/bad, unlikable/pleasing, unpleasant/pleasant, attractive/ unattractive, friendly/unfriendly.

2. Efisiensi (efficiency)

Seberapa cepat pengguna dapat menyelesaikan tugas. Item ukuran: fast/slow, inefficient/efficient, impractical/practical, organized/cluttered.

3. Kejelasan (perspicuity)

Seberapa mudah suatu produk dapat digunakan. Item ukuran: not understandable/ understandable, easy to learn/difficult to learn, complicated/ easy, clear/confusing.

4. Ketepatan (dependability) 
Kumpulan Artikel Mahasiswa Pendidikan Teknik Informatika

(KARMAPATI)

Volume 10, Nomor 1, Tahun 2021

Apakah interaksi dapat dikendalikan oleh pengguna? Item ukuran: unpredictable/predictable, obstructive/ supportive, secure not secure, meets expectations/does not meet expectations.

5. Stimulasi (stimulation)

Seberapa baik suatu produk untuk memotivasi pengguna. Item ukuran: valuable/inferior, boring/exiting, not interesting/interesting, motivating/demotivating.

6. Kebaruan (novelty)

Seberapa inovatif suatu produk. Item ukuran: creative/dull, inventive/ conventional, usual leading edge, conservative/innovative.

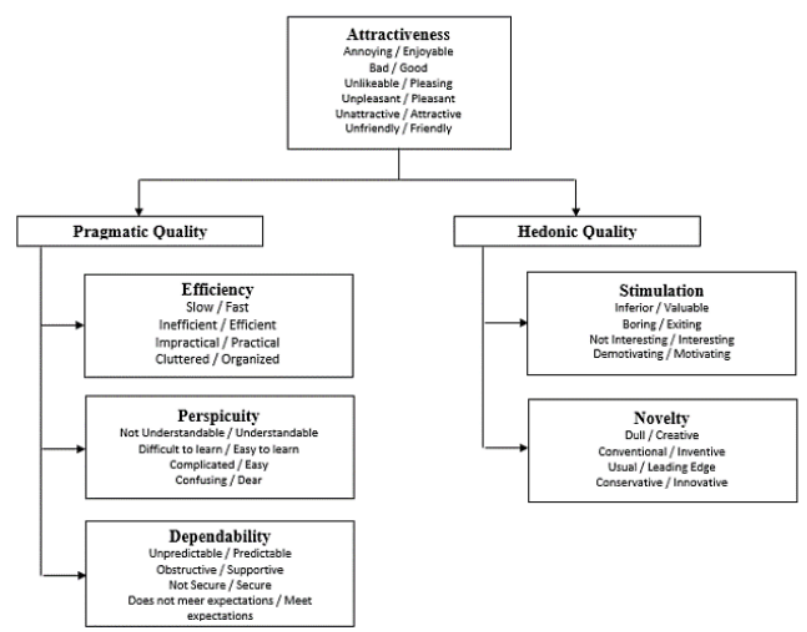

Gambar 1. Skala Pengukuran UEQ

Reliabilitas dan validitas dari skala UEQ telah diselidiki sebelumnya dalam beberapa penelitian (dalam 11 usability test dengan jumlah total 144 peserta dan survei online dengan 722 peserta). Studi menunjukkan bahwa reliabilitas dari $U E Q$ cukup tinggi dengan menggunakan koefisen Cronbach-Alpha untuk estimasi konsistensi internal. Selain itu, hasil dari beberapa penelitian menunjukkan skala validitas yang baik. Setiap butir dari kuesioner diwujudkan sebagai diferensial semantik, yaitu setiap butirnya terdiri dari sepasang istilah dengan makna berlawanan (contoh: menyusahkan menyenangkan). Hasil akhir dari $U E Q$ digambarkan dalam grafik benchmark yang menunjukkan kualitas dari produk ke dalam lima kategori yaitu: excellent, good, above average, below average dan bad.
Tabel 1. Kategori pada UEQ Data Analysis Tool

\begin{tabular}{|c|c|c|c|c|c|c|}
\hline \multirow{2}{*}{ No } & \multirow{2}{*}{ Aspek } & Excellent & Good & $\begin{array}{c}\text { Above } \\
\text { Average }\end{array}$ & $\begin{array}{c}\text { Below } \\
\text { Average }\end{array}$ & Bad \\
\cline { 3 - 7 } & $\begin{array}{c}\text { Daya } \\
\text { Tarik }\end{array}$ & $>1.75$ & $>1.52$ & $>1.17$ & $>0.7$ & $<=0.7$ \\
\hline 2 & Kejelasan & $>1.9$ & $>1.56$ & $>1.08$ & $>0.64$ & $<=0.64$ \\
\hline 3 & Efisiensi & $>1.78$ & $>1.47$ & $>0.98$ & $>0.54$ & $<=0.54$ \\
\hline 4 & Ketepatan & $>1.65$ & $>1.48$ & $>1.14$ & $>0.78$ & $<=0.78$ \\
\hline 5 & Stimulasi & $>1.55$ & $>1.31$ & $>0.99$ & $>0.5$ & $<=0.5$ \\
\hline 6 & Kebaruan & $>1.4$ & $>1.05$ & $>0.71$ & $>0.3$ & $<=0.3$ \\
\hline
\end{tabular}

User Experience Questionnaire merupakan suatu alat bantu pengolahan data survei terkait pengalaman pengguna yang mudah diaplikasikan, terpercaya dan valid, yang dapat digunakan untuk melengkapi data dari metode evaluasi lain dengan penilaian kualitas subjektif.

\section{Metodologi Penelitian}

A. Metode Pengumpulan Data

Pada penelitian ini, peneliti mengumpulkan data menggunakan metode kuantitatif, yaitu metode penelitian yang digunakan untuk menjawab masalah penelitian yang berkaitan dengan data berupa angka dan program statistik[6]. Kuesioner merupakan teknik pengumpulan data yang dilakukan dengan cara memberi seperangkat pernyataan tertulis kepada responden untuk di jawabnya. Kuesioner merupakan teknik pengumpulan data yang efisien bila peneliti tahu pasti variabel yang akan diukur dan tahu apa yang bisa diharapkan dari responden[10]. Dalam metode ini, peneliti menggunakan User Experience Questionnaire untuk mengukur tingkat kepuasan pengguna dan melakukan wawancara untuk menjadi acuan menyusun rekomendasi perbaikan.

\section{B. Alur Penelitian}

Penelitian dimulai dengan mengidentifikasi masalah yang terjadi, yaitu ditemukannya pengguna yang kebingungan saat menggunakan sistem informasi PRISKA, sehingga peneliti merasa perlu dilakukannya evaluasi terkait pengalaman pengguna selama menggunakan sistem informasi tersebut. Kemudian, dilakukannya studi literatur untuk mempelajari teknik yang dapat digunakan untuk melakukan evaluasi terhadap suatu sistem beserta penelitian terkait yang pernah dilakukan, baik dari buku, jurnal, artikel, paper, maupun sumber dari internet. Selanjutnya, dilakukan proses pengumpulan data dengan menentukan responden yang 
2685-7006|p-ISSN: 2252-9063

Kumpulan Artikel Mahasiswa Pendidikan Teknik Informatika

(KARMAPATI)

Volume 10, Nomor 1, Tahun 2021

digunakan dalam penelitian ini yakni pengguna PRISKA (mahasiswa yang mengambil mata kuliah proposal, mahasiswa yang mengambil mata kuliah skripsi, dosen). Data yang dikumpulkan bersifat kuantitatif, yaitu melalui kuesioner dengan metode User Experience Questionnaire (UEQ) untuk mengetahui user experience sistem informasi PRISKA. Setelahnya, dilakukan analisis terhadap data yang sudah dikumpulkan sebelumnya, dan hasil dari analisa data ini akan dijadikan acuan atau saran kepada pengembang PRISKA melalui pemberian rekomendasi.

\section{HASIL DAN PEMBAHASAN}

\section{A. Evaluasi User Experience Questionnaire}

\section{User Mahasiswa}

Evaluasi sistem informasi Primakara Skripsi dan Tugas Akhir (PRISKA) yang dilakukan oleh peneliti menggunakan metode User Experience Questionnaire (UEQ) dengan penyebaran kuesioner berisi 26 butir pertanyaan yang diberikan kepada pengguna sistem informasi PRISKA di STMIK Primakara. Jumlah responden yang mengisi kuesioner adalah 94 orang. Masing - masing pertanyaan memiliki skala $1-7$, yang tiap butir pertanyaannya terdiri dari pasangan atribut bertolak belakang secara makna yang dapat merepresentasikan produk.

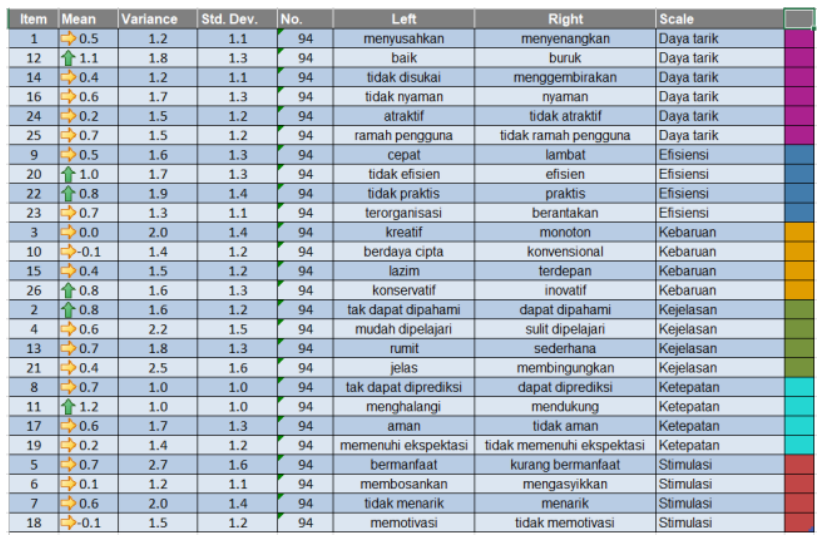

Gambar 2. Mean, Varian dan Simpangan Baku user Mahasiswa

Dari 94 jawaban responden, untuk setiap pertanyaannya dilakukan perhitungan mean, varian, dan simpangan baku. Masing - masing pertanyaan diberikan kode warna sesuai dengan kelompoknya, yakni daya tarik, efisiensi, kebaruan, kejelasan dan stimulasi. Nilai rata-rata antara $>0.8$ mewakili evaluasi positif (tanda panah arah atas berwarna hijau), nilai rata-rata $<-0.8$ mewakili evaluasi negatif (tanda panah arah bawah warna merah) dan apabila nilai rata-rata berada diantara nilai evaluasi positif dan negatif, maka mewakili nilai netral (tanda panah arah kanan berwarna kuning).

\begin{tabular}{|l|l|r|}
\hline \multicolumn{3}{|c|}{ UEQ Scales (Mean and Variance) } \\
\hline Daya tarik & $\Rightarrow 0.587$ & 0.88 \\
\hline Kejelasan & $\Rightarrow 0.628$ & 1.43 \\
\hline Efisiensi & 0.755 & 1.09 \\
\hline Ketepatan & $\Rightarrow 0.670$ & 0.66 \\
\hline Stimulasi & $\Rightarrow 0.306$ & 1.21 \\
\hline Kebaruan & $\Rightarrow 0.277$ & 0.82 \\
\hline
\end{tabular}

Gambar 3. Rata-rata impresi dan varian skala user Mahasiswa

Gambar 3 menunjukkan nilai rata-rata dari keseluruhan item pertanyaan sesuai kelompoknya. Hasil nilai rata-rata dari daya tarik, kejelasan, efisiensi, ketepatan, stimulasi dan kebaruan mendapat impresi netral.

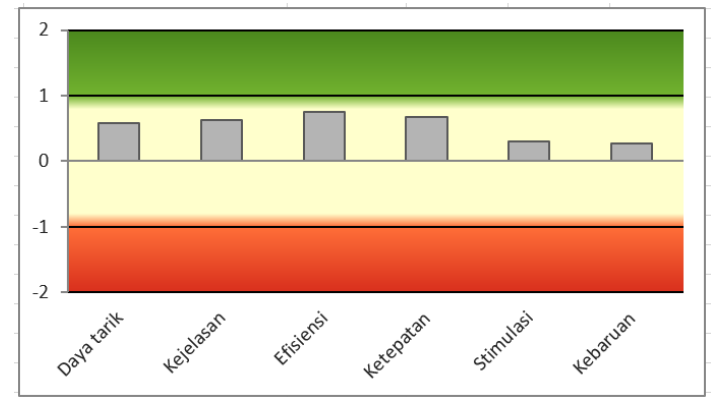

Gambar 4. Grafik rata-rata impresi user Mahasiswa

Gambar 4 dapat disimpulkan bahwa sistem informasi PRISKA user mahasiswa pada skala efisiensi cenderung memiliki impresi positif (nilai mendekati angka 1 dan seterusnya). Sedangkan untuk skala daya tarik, kejelasan, ketepatan, stimulasi dan kebaruan berada pada impresi netral.

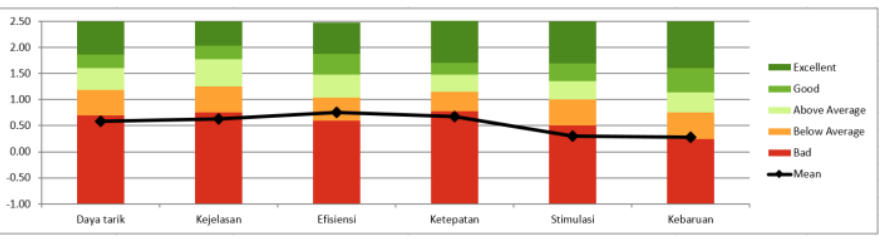

Gambar 5. Standar Set Data Benchmark user Mahasiswa

Pada gambar 5, skala daya tarik mencapai nilai rata-rata 0.59. Selanjutnya, pada skala kejelasan, mendapat nilai ratarata 0.63 . Skala efisiensi mendapatkan nilai rata-rata 0.76 . 
2685-7006|p-ISSN: 2252-9063

Kumpulan Artikel Mahasiswa Pendidikan Teknik Informatika

(KARMAPATI)

Volume 10, Nomor 1, Tahun 2021

Kemudian, pada skala ketepatan mendapatkan nilai rata-rata 0.67. Skala stimulasi mendapatkan nilai rata-rata 0.31 dan terakhir skala kebaruan mendapatkan nilai rata-rata 0.28 . Hasil rataan yang dapat membantu analisa selanjutnya yaitu menentukkan set data benchmark sebagai perbandingan produk Primakara Skripsi dan Tugas Akhir (PRISKA) dengan 246 produk kumpulan dari set data benchmark. Berikut hasil perbandingan:

Tabel 2. Hasil Set Data Benchmark user Mahasiswa

\begin{tabular}{|c|c|c|c|}
\hline $\begin{array}{c}\text { Daya } \\
\text { Tarik }\end{array}$ & 0.59 & Bad & $\begin{array}{c}\text { Dikisaran 25\% hasil } \\
\text { terburuk }\end{array}$ \\
\hline Kejelasan & 0.63 & Bad & $\begin{array}{c}\text { Dikisaran 25\% hasil } \\
\text { terburuk }\end{array}$ \\
\hline Efisiensi & 0.76 & $\begin{array}{c}\text { Below } \\
\text { Average }\end{array}$ & $\begin{array}{c}50 \% \text { dari hasil lebih } \\
\text { baik, 25\% hasilnya } \\
\text { lebih buruk }\end{array}$ \\
\hline Ketepatan & 0.67 & Bad & $\begin{array}{c}\text { Dikisaran 25\% hasil } \\
\text { terburuk }\end{array}$ \\
\hline Stimulasi & 0.31 & Bad & $\begin{array}{c}\text { Dikisaran 25\% hasil } \\
\text { terburuk }\end{array}$ \\
\hline Kebaruan & 0.28 & Below & $\begin{array}{c}50 \% \text { dari hasil lebih } \\
\text { baik, 25\% hasilnya } \\
\text { lebih buruk }\end{array}$ \\
\hline
\end{tabular}

Berdasarkan tabel 2, dapat disimpulkan bahwa sistem informasi PRISKA berdasarkan user mahasiswa perlu dilakukanya perbaikan user interface pada skala daya tarik, kejelasan, ketepatan dan stimulasi dari segi user experience.

\section{User Dosen}

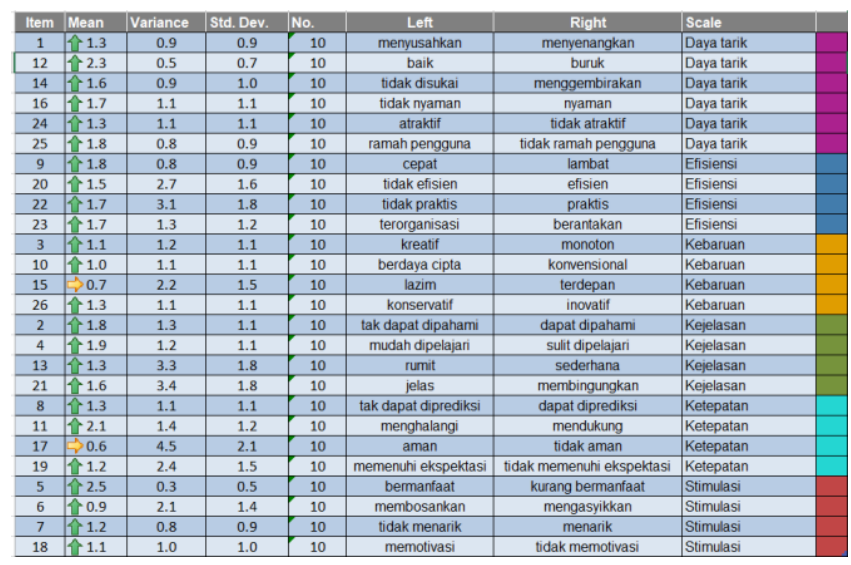

Gambar 6. Mean, Varian dan Simpangan Baku user Dosen
Dari 10 jawaban responden, untuk setiap pertanyaannya dilakukan perhitungan mean, varian, dan simpangan baku. Masing - masing pertanyaan diberikan kode warna sesuai dengan kelompoknya, yakni daya tarik, efisiensi, kebaruan, kejelasan dan stimulasi. Nilai rata-rata antara $>0.8$ mewakili evaluasi positif (tanda panah arah atas berwarna hijau), nilai rata-rata $<-0.8$ mewakili evaluasi negatif (tanda panah arah bawah warna merah) dan apabila nilai rata-rata berada diantara nilai evaluasi positif dan negatif, maka mewakili nilai netral (tanda panah arah kanan berwarna kuning).

\begin{tabular}{|l|c|r|}
\hline \multicolumn{3}{|c|}{ UEQ Scales (Mean and Variance) } \\
\hline Daya tarik & 亿 1.667 & 0.54 \\
\hline Kejelasan & 亿 1.650 & 1.89 \\
\hline Efisiensi & 亿 1.675 & 1.54 \\
\hline Ketepatan & 亿 1.300 & 1.47 \\
\hline Stimulasi & 亿 1.425 & 0.74 \\
\hline Kebaruan & 亿 1.025 & 1.03 \\
\hline
\end{tabular}

Gambar 7. Rata-rata impresi dan varian skala user Dosen

Gambar 7 menunjukkan nilai rata-rata dari keseluruhan item pertanyaan sesuai kelompoknya. Hasil nilai rata-rata dari daya tarik, kejelasan, efisiensi, ketepatan, stimulasi dan kebaruan mendapat impresi positif.

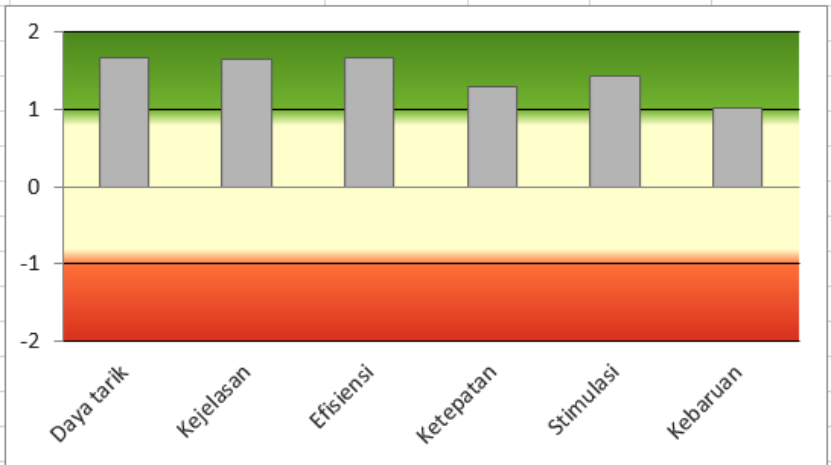

Gambar 8. Grafik rata-rata impresi user Dosen

Pada gambar 8 dapat disimpulkan bahwa sistem informasi PRISKA user Dosen cenderung memiliki impresi positif pada setiap skalanya (nilai mendekati angka 1 dan seterusnya). 
2685-7006 | p-ISSN: 2252-9063

Kumpulan Artikel Mahasiswa Pendidikan Teknik Informatika

(KARMAPATI)

Volume 10, Nomor 1, Tahun 2021

KคRMAPคTI

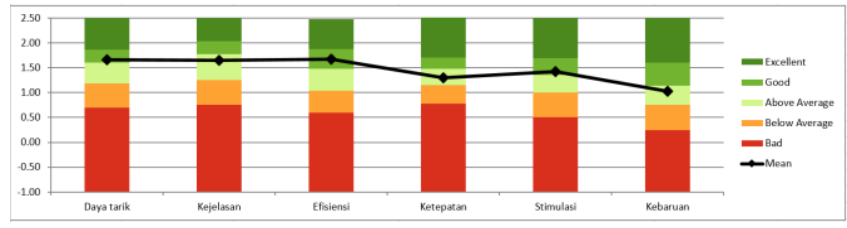

Gambar 9. Standar Set Data Benchmark user Dosen

Pada gambar 9, skala daya tarik mencapai nilai rata-rata 2.08. Selanjutnya, pada skala kejelasan, mendapat nilai ratarata 2.38. Skala efisiensi mendapatkan nilai rata-rata 2.13. Kemudian, pada skala ketepatan mendapatkan nilai rata-rata 2.13. Skala stimulasi mendapatkan nilai rata-rata 2.13 dan terakhir skala kebaruan mendapatkan nilai rata-rata 2.25. Hasil rataan yang dapat membantu analisa selanjutnya yaitu menentukkan set data benchmark sebagai perbandingan produk Primakara Skripsi dan Tugas Akhir (PRISKA) dengan 246 produk kumpulan dari set data benchmark. Berikut hasil perbandingan:

Tabel 3. Hasil Set Data Benchmark user Dosen

\begin{tabular}{|c|c|c|c|}
\hline Daya Tarik & 1.67 & Good & $\begin{array}{c}10 \% \text { dari hasil lebih baik, } \\
75 \% \text { hasilnya lebih buruk }\end{array}$ \\
\hline Kejelasan & 1.65 & $\begin{array}{c}\text { Above } \\
\text { Average }\end{array}$ & $\begin{array}{l}25 \% \text { dari hasil lebih baik, } \\
50 \% \text { hasilnya lebih buruk }\end{array}$ \\
\hline Efisiensi & 1.68 & Good & $\begin{array}{l}10 \% \text { dari hasil lebih baik, } \\
75 \% \text { hasilnya lebih buruk }\end{array}$ \\
\hline Ketepatan & 1.30 & $\begin{array}{c}\text { Above } \\
\text { Average }\end{array}$ & $\begin{array}{l}25 \% \text { dari hasil lebih baik, } \\
50 \% \text { hasilnya lebih buruk }\end{array}$ \\
\hline Stimulasi & 1.43 & $\begin{array}{c}\text { Good } \\
10 \% \text { dari hasil lebih baik, } \\
75 \% \text { hasilnya lebih buruk }\end{array}$ \\
\hline Kebaruan & 1.03 & $\begin{array}{c}\text { Above } \\
\text { Average }\end{array}$ & $\begin{array}{l}25 \% \text { dari hasil lebih baik, } \\
50 \% \text { hasilnya lebih buruk }\end{array}$ \\
\hline
\end{tabular}

Berdasarkan tabel 3, dapat disimpulkan bahwa sistem informasi PRISKA berdasarkan user dosen tidak ada kekurangan pada setiap kelompoknya. Untuk pembahasan mengenai rekomendasi perbaikan, peneliti hanya memberikan rekomendasi perbaikan terkait user interface dari pengguna mahasiswa, sedangkan untuk dosen tidak diberikan mengingat impresi yang diberikan cenderung positif dan puas akan sistem yang sudah berjalan.

\section{B. Rekomendasi Perbaikan}

Untuk memperoleh rekomendasi perbaikan terhadap sistem informasi PRISKA dilakukan wawancara terhadap 94 orang mahasiswa yang dilihat dari hasil set data benchmark
UEQ. Rekomendasi pertama membahas tampilan pada bagian dashboard atau tampilan utama dari PRISKA, dimana sebaiknya diberikan informasi penting seperti jadwal untuk pengajuan topik proposal, jadwal bimbingan, maupun jadwal untuk ujian agar mahasiswa tidak perlu mencari informasi terkait tugas akhir pada platform lain. Serta tulisan dashboard berganti menjadi "Home" guna memudahkan mahasiswa paham dengan fitur yang ada pada PRISKA. Gambar 10 merupakan tampilan awal PRISKA, kemudian gambar 11 adalah tampilan PRISKA setelah diberikan rekomendasi perbaikan oleh peneliti.

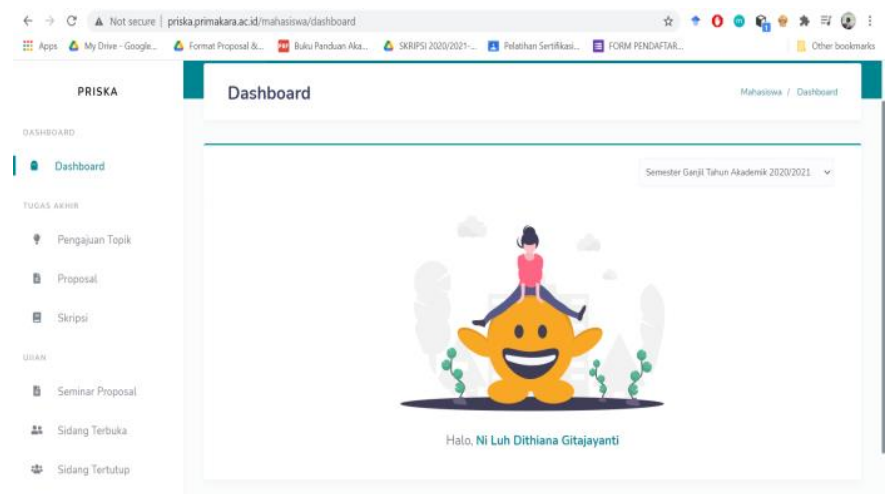

Gambar 10. Tampilan Utama PRISKA pada user Mahasiswa

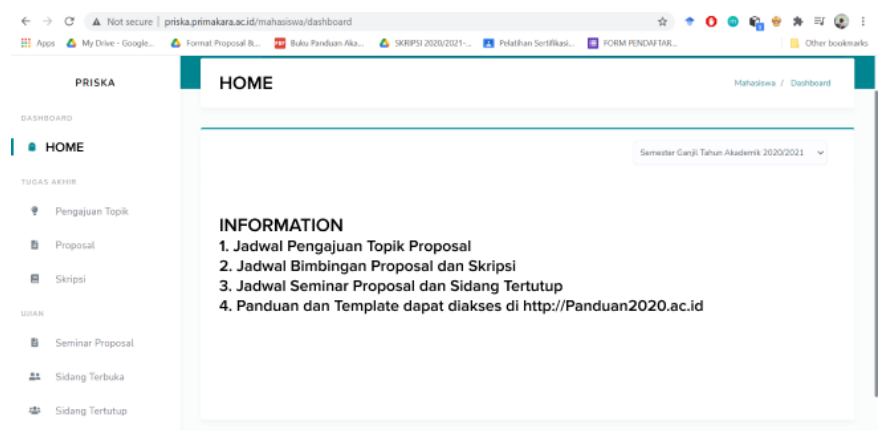

Gambar 11. Rekomendasi untuk Tampilan Utama PRISKA pada user Mahasiswa

Rekomendasi kedua yaitu pada bagian pengajuan topik proposal, dimana pada proses bisnisnya "mahasiswa mengajukan permohonan usulan tema/topik skripsi sebanyak 3 tema/topik ke Kepala Program Studi." Sehingga disini terjadi kebingungan pada mahasiswa, bagaimana caranya mengajukan lebih dari satu topik pada hanya satu kolom yang tersedia. Perlu adanya sosialisasi bila dalam satu kolom ini bisa langsung dimasukkan ketiga topik yang akan diajukan ke dosen. Pada bagian keterangan bisa juga diberikan instruksi 
e-ISSN: 2685-7006|p-ISSN: $2252-9063$

"Keterangan Anda memilih topik yang diusulkan." Gambar 12 merupakan tampilan awal PRISKA, kemudian gambar 13 adalah tampilan PRISKA setelah diberikan rekomendasi perbaikan oleh peneliti.

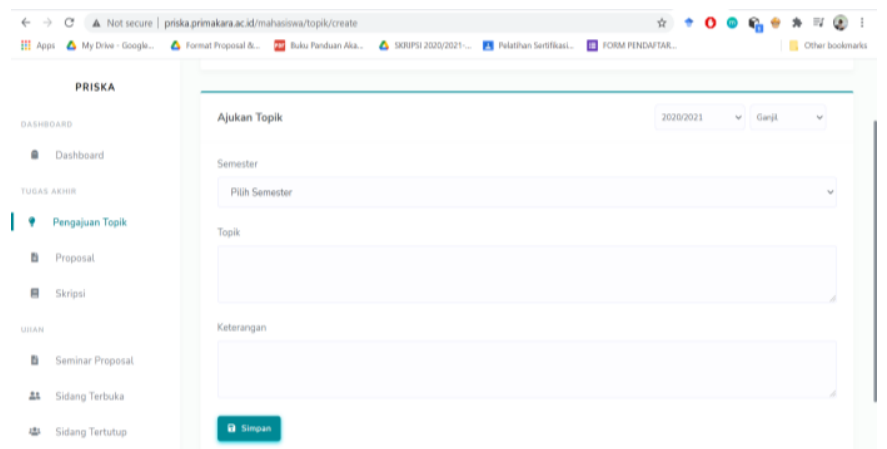

Gambar 12. Tampilan Pengajuan Topik ada user Mahasiswa

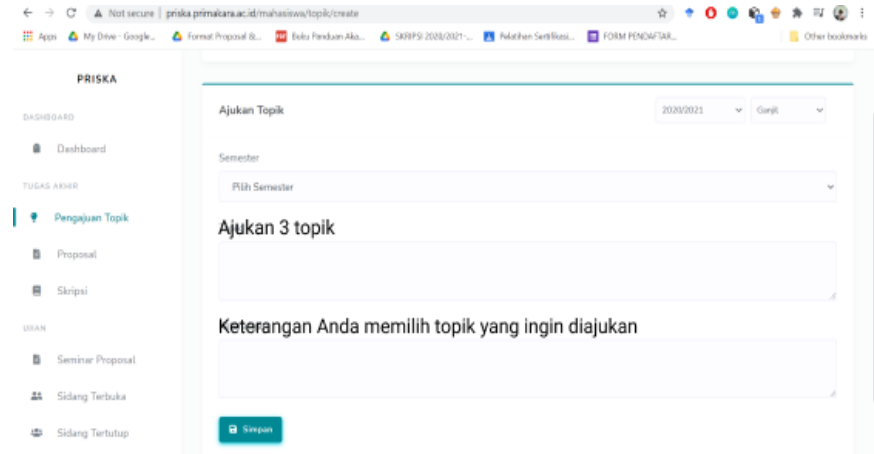

Gambar 13. Rekomendasi untuk Tampilan Pengajuan Topik pada user Mahasiswa

Rekomendasi ketiga pada fitur "Seminar Proposal" atau pun "Sidang Terbuka" / "Sidang Tertutup", terdapat kolom dimana tempat mengunggah Tugas Akhir seharusnya diberikan keterangan dalam bentuk format apa, sehingga mahasiswa merasa jelas file apa yang harus diunggah oleh mahasiswa. Terdapat tambahan berupa kolom untuk mengunggah link ujian dan plagiarism checker. Gambar 14 merupakan tampilan awal PRISKA, kemudian gambar 15 adalah tampilan PRISKA setelah diberikan rekomendasi perbaikan oleh peneliti.

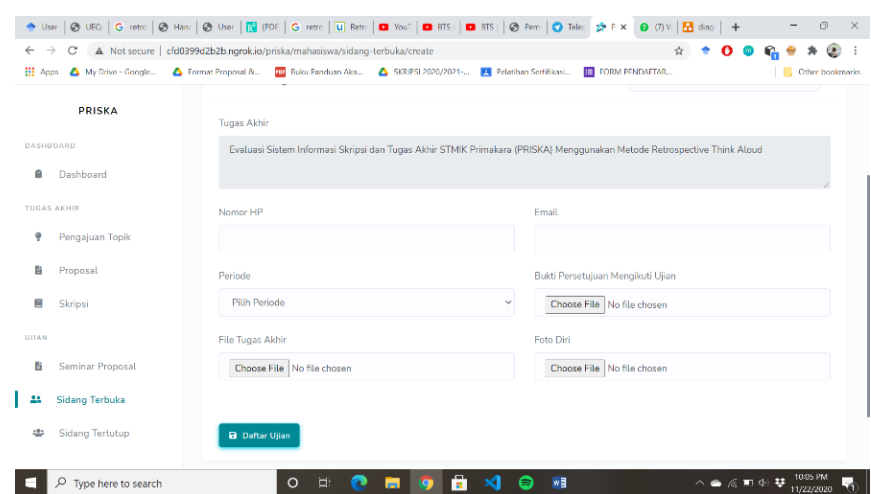

Gambar 14. Tampilan Sidang Terbuka user Mahasiswa

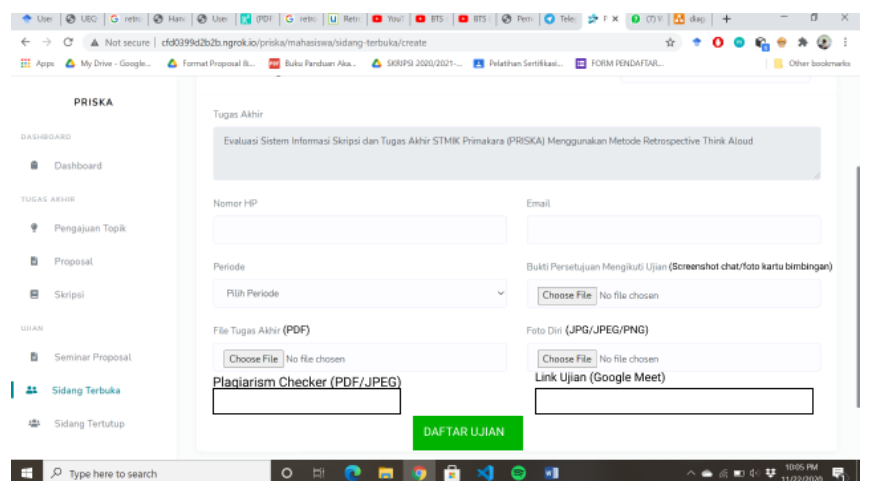

Gambar 15. Rekomendasi untuk Tampilan Sidang Terbuka user Mahasiswa

Rekomendasi keempat Pada fitur "Seminar Proposal"" atau pun "Sidang Terbuka" / "Sidang Tertutup", saat user akan melakukan perubahan pada data dirinya, user mengalami kebingungan dikarenakan pada kolom "File Tugas Akhir", "Bukti Persetujuan Mengikuti Ujian", dan kolom "Foto Diri", file seolah belum terupload. Hal ini karena adanya tombol "Choose File" yang membuat user berpikir untuk mengunggah Kembali file-file sebelumnya yang sudah terunggah. Sehingga, perlu diberitahukannya bahwa file tersebut sudah terunggah ke database agar user tidak mengalami kebingungan saat melakukan perubahan data diri. Gambar 16 merupakan tampilan awal PRISKA, kemudian gambar 17 adalah tampilan PRISKA setelah diberikan rekomendasi perbaikan oleh peneliti. 
2685-7006|p-ISSN: 2252-9063

Kumpulan Artikel Mahasiswa Pendidikan Teknik Informatika

(KARMAPATI)

Volume 10, Nomor 1, Tahun 2021

KคRMดPดTI

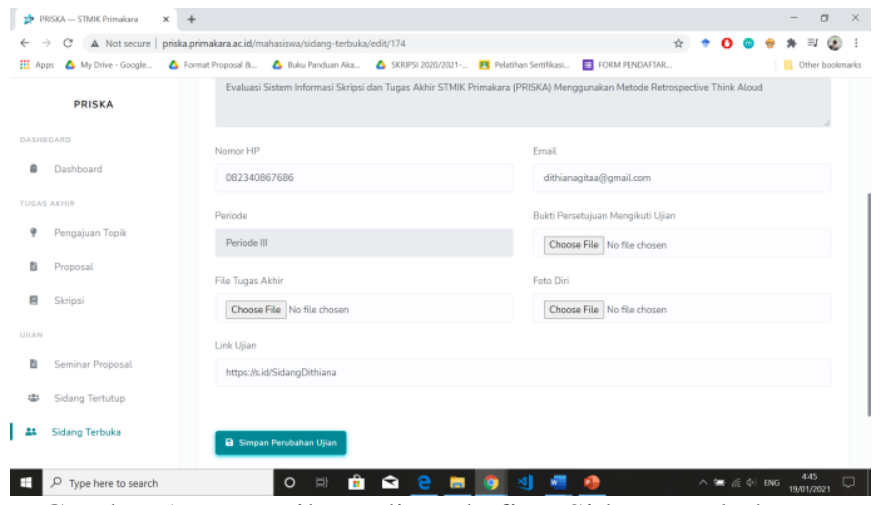

Gambar 16. Tampilan Edit pada fitur Sidang Terbuka user Mahasiswa

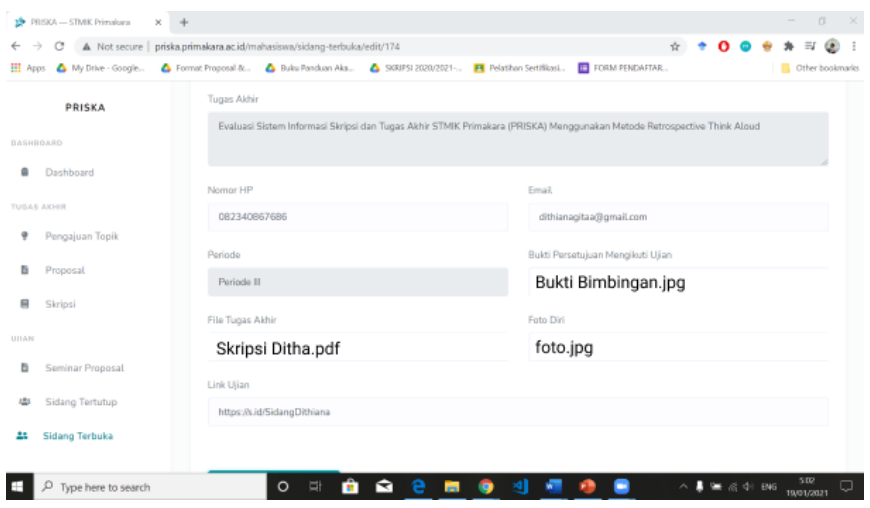

Gambar 17. Rekomendasi untuk Tampilan Edit pada fitur Sidang Terbuka user Mahasiswa

Rekomendasi di atas berdasarkan hasil evaluasi dengan pengguna Sistem Informasi PRISKA yaitu user Mahasiswa. Sedangkan untuk user Dosen, impresi yang ditujukan cenderung positif dan tidak mengalami kesulitan saat berinteraksi dengan sistem. Rekomendasi diharapkan dapat menjadi masukan untuk pengembang sistem dalam mengembangkan Sistem Informasi PRISKA serta meningkatkan efektivitas untuk para penggunanya.

\section{PENUTUP}

Berdasarkan dari pembahasan yang telah diuraikan pada setiap bab untuk evaluasi sistem informasi Primakara Skripsi dan Tugas Akhir (PRISKA), peneliti dapat menarik kesimpulan sebagai berikut:

1. Dengan metode User Experience Questionnaire (UEQ), peneliti dapat menggali persepsi setiap user serta kepuasan user saat menggunakan sistem informasi PRISKA. Diketahui bahwa hasil UEQ menunjukkan impresi dari user mahasiswa tergolong netral, yaitu pada skala daya tarik mendapatkan nilai 0.587 , skala kejelasan mendapatkan nilai 0.628 , skala efisiensi mendapatkan nilai 0.755 , skala ketepatan mendapatkan nilai 0.670 , skala stimulasi mendapatkan nilai 0.306 dan skala kebaruan mendapatkan nilai 0.277. Untuk user dosen memberikan impresi positif, dengan skala daya tarik mendapatkan nilai 1.667 , skala kejelasan mendapatkan nilai 1.650, skala efisiensi mendapatkan nilai 1.675 , skala ketepatan mendapatkan nilai 1.300 , skala stimulasi mendapatkan nilai 1.425 dan skala kebaruan mendapatkan nilai 1.025.

2. Rekomendasi perbaikan yang diberikan oleh peneliti hanya untuk user interface bagi pengguna mahasiswa, sedangkan untuk pengguna dosen tidak diberikan mengingat impresi yang diberikan cenderung positif dan puas akan sistem yang sedang berjalan. Namun, masih tetap diperlukannya peningkatan fungsionalitas yang ada pada sistem informasi PRISKA. Hasil rekomendasi masih berupa desain yang belum dilakukannya penelitian lebih lanjut, sehingga perlu kajian atau pengembangan lebih lanjut mengenai rekomendasi yang telah peneliti lakukan.

\section{REFERENSI}

[1] Safrian Aswati, Neni Mulyani, Yessica Siagian, Arridha Zikra Syah, "Peranan Sistem Informasi dalam Perguruan Tinggi," Sumatera Utara: STMIK Royal Kisaran Sumatera Utara, 2015.

[2] Jakob Nielsen, "Usability 101: Introduction to Usability," 2012 https://www.nngroup.com/articles/usability-101-introduction-tousability/ (diakses pada 29 juli 2020)

[3] H. B. Santoso, M. Schrepp., R. Y. K. Isal., A. Y. Utomo., and B. Priyogi., "Measuring User Experience of the Student-Centered e-Learning Environment," J. Educ. Online-JEO January 2016 ISSN 1547-500X Vol 13 Number 1, vol. 13, no. 1, pp. 58-79, 2016

[4] A. M. Gray and H. Wardle, "Observing gambling behaviour using think-aloud and video technology A methodological review," Natl. Cent. Soc. Res., no. February 2012, 2013.

[5] Usability.gov, "Running a Usability Test." [Online]. Available: https://www.usability.gov/how-toandtools/methods/runningusability-tests.html. (diakses pada 01 Agustus 2020).

[6] Dr. Wahidmurni, M.Pd, "Pemaparan Metode Penelitian Kuantitatif," Malang: UIN Maulana Malik Ibrahim, 2017

[7] Schrepp, Martin \& Hinderks, Andreas \& Thomaschewski, Jörg. (2017). Design and Evaluation of a Short Version of the User Experience Questionnaire (UEQ-S). International Journal of Interactive Multimedia and Artificial Intelligence. 4. 103. 10.9781/ijimai.2017.09.001. 
e-ISSN: 2685-7006 | p-ISSN: 2252-9063

Kumpulan Artikel Mahasiswa Pendidikan Teknik Informatika

(KARMAPATI)

Volume 10, Nomor 1, Tahun 2021

\section{KดRmดPดTI}

[8] P. D. Sugiyono, "Metode Penelitian Kombinasi (Mixed Method) (Cetakan Ke)," Bandung: Alfabeta, 2013.

[9] Prof. Dr. Sugiyono, "Metode Penelitian Kuantitatif, Kualitatif, dan R\&D cetakan ke-28," Bandung: Alfabeta, 2018.

[10] P. D. Sugiyono, "Metode Penelitian Kuantitatif, Kualitatif dan R\&D," Bandung: Alfabeta, 2012. 